\title{
RA?EGA
}

O ESPACO GEOGRÁFICO EM ANÁLISE

\section{A TERRITORIALIZAÇÃO LIBANESA EM GUARAPUAVA PR.}

\section{THE TERRITORIALIZATION OF LEBANESE IN GUARAPUAVA PR.}

\author{
Anderson Muzzolon \\ Discente do Programa de Pós-Graduação de Mestrado \\ Geografia da Universidade Estadual do Centro Oeste (UNICENTRO) \\ Guarapuava, PR, Brasil. \\ e-mail:anderson_muzzolon@yahoo.com.br
}

Artigo recebido em: 12/09/2012.

Artigo aceito em: 29/10/2013.

\section{Resumo}

A análise das relações sócio-espaciais ao longo do tempo, constituídas pelo processo de territorializacão de grupos culturais na cidade, é uma forma de compreender a dinâmica de produção de parcelas do espaço urbano. Este é o enfoque que procuramos desenvolver em relação aos libaneses e descendentes que moram em Guarapuava, buscando o propósito de reconstruir sua trajetória na cidade e sua contribuição para a consolidação de duas importantes ruas comerciais do centro urbano: as ruas Guaíra e Saldanha Marinho. A pesquisa teve como fontes principais documentos diversos, tanto da prefeitura municipal, museu e biblioteca municipal, quanto dos próprios libaneses, e, sobretudo, a memória das várias gerações deste grupo cultural, a qual buscamos acessar por meio de entrevistas. Com isso, a pesquisa procurou preencher uma lacuna nos estudos sobre a cidade de Guarapuava, pela consideração de um grupo negligenciado, até o momento, pela historiografia e geografia.

Palavras-Chave: Cultura, memória, território, produção do espaço urbano.

\section{Abstract}

The analysis of socio-spatial relations over time, constituted by the process of territorialization of cultural groups in the city, is a form to understand the dynamics of parcels production of urban space. This is the focus that we develop in relation to the Lebanese and descendants who live in Guarapuava, for the purpose of seeking to reconstruct its trajectory in the city and its contribution to the consolidation of two important commercial streets of the urban center: the streets Guaíra and Saldanha Marinho. The research had as major sources different documents from both the city hall, museum and municipal library, as the Lebanese themselves, and above all the 
memory of many generations of this cultural group, which we seek access by interviews. With this, The research sought to fill a gap in studies about the city of Guarapuava by the consideration of a neglected group, until the moment, for the historiography and geography.

Keywords: Culture, memory, territory, production of urban space.

\section{INTRODUÇÃO}

Neste artigo buscamos entender parte da formação do espaço histórico urbano de Guarapuava, partindo do princípio que os discursos que explicam a formação das cidades são incompletos e acabam negligenciando a influência de algumas das culturas que o compõem e compuseram, ao passo que reforçam e salientam outras.

Acreditamos que as formas de explicar o processo de formação espacial da cidade de Guarapuava foram construídas segundo certa perspectiva. Então, a análise da territorialização libanesa nesse contexto e sua contribuição na produção do seu espaço urbano, bem como os conflitos, os fluxos e a relações dialógicas inerentes a esse processo não se mostram nos discursos que reconstroem a formação da cidade.

A cidade de Guarapuava-Pr é formada por grande diversidade de grupos culturais. Apesar disso, tem-se pouco conhecimento de como estas culturas contribuíram para a concretização desse "mosaico cultural", que percebemos hoje. A contribuição que cada uma deu, para formar aquilo que se constitui como espaço urbano de Guarapuava, ainda é uma incógnita. No esforço de suprimirmos essa lacuna e contribuirmos com a inserção desse grupo cultural na história da cidade, é que conduzimos nossa pesquisa.

As migrações favoreceram trocas importantes nos campos da cultura, da economia e da política ao longo dos milênios, além de serem responsáveis pelo desaparecimento e/ou surgimento de grupos culturais, cujos suportes são híbridos, por acolherem traços dos diversos povos com os quais os migrantes entraram em contato.

Para Massey (2000), o lugar pode ser entendido como lócus de encontro de várias redes de relações sociais, complexas trajetórias que, juntas, contribuem para a sua construção. 
Nesta pesquisa foram analisadas as trajetórias de experiências de imigrantes libaneses que chegaram à cidade de Guarapuava PR, desde o final do século XIX. Procuramos compreender as ações desses sujeitos na transformação urbana, bem como os conflitos vivenciados com outros grupos locais e mesmo dentro do próprio grupo, pela conquista do espaço e do direito de pertencimento ao lugar.

\section{DES-RE-TERRITORIALIZAÇÃO LIBANESA E A FORMAÇÃO DO LUGAR: PRODUÇÃO ECONÔMICA E CULTURAL DO ESPAÇO URBANO.}

Os libaneses sempre viram o Brasil, de uma forma ou de outra, como um dos melhores países para se imigrar. Isso se percebe nos depoimentos de todos os libaneses que vieram morar aqui. Esta é uma visão que se percebe em todos os trabalhos que lemos e todas as entrevistas que realizamos durante este período de pesquisa, em que os brasileiros, de uma forma geral, são vistos como muito receptivos aos imigrantes libaneses, os quais dependiam diretamente dessa receptividade para prosperar e aumentar suas comunidades.

A primeira cidade de referência é São Paulo. Normalmente, chegam à casa de um parente e depois recebem informações sobre outros lugares com potencialidade para trabalhar. Assim foi com Guarapuava. Os entrevistados que chegaram aqui até a década de 1950, tinham referências principalmente de Ponta Grossa, normalmente já tinham algum parente residindo nesta cidade. Já os mais recentes ao chegar em São Paulo, falam de outras cidades, principalmente Foz do Iguaçu e Curitiba.

Assim, os motivos da dispersão dos libaneses pelo território brasileiro se dão em função da busca por mercados onde se possa trabalhar com vendas, explorando nichos onde se identificavam oportunidade de negócios.

Segundo Khodr (1987, p. 50), os libaneses, "em sua quase totalidade, imigraram individualmente e não em colônias. Além disso, em vez de se dirigirem à agricultura, foram comerciar e, assim sendo, tiveram que aprender a língua portuguesa de forma mais rápida". Percebe-se que tal fato favoreceu a integração à vida brasileira. Assim, suas relações foram diferentes de outros imigrantes que, muitas vezes, conviviam isolados em colônias. 
De modo geral, os imigrantes trouxeram muito pouco ou nenhum capital. Desse modo, o comércio oferecia uma recompensa financeira mais rápida que a agricultura, pois não exigia a aquisição de terras e investimentos iniciais. Como a mercadoria para o comércio podia-se obter a crédito e o retorno era mais rápido e lucrativo, essa era uma forma conveniente de se obter capital, a mercadoria ou o capital podia ser conseguido, por meio de empréstimos junto aos patrícios do Líbano que aqui residiam.

O estado do Paraná recebeu imigrantes sírios e libaneses desde quando essa corrente migratória começou a se dirigir ao Brasil, de forma sistemática. Assim, temos registros em cidades como Curitiba, Ponta Grossa e Guarapuava, que mostram sua presença já no final do século XIX e início do XX.

A dispersão pelo Paraná sempre se deu a partir de referências de famílias que já estavam morando no Estado que, de uma forma ou de outra, ajudavam na escolha dos locais para morar, como é o caso de Rita Reda ${ }^{1}$ que veio morar em Guarapuava no início da década de 1980, em busca de novas oportunidades comerciais, por indicação de seus parentes que já estavam estabelecidos em Ponta Grossa.

A- Que motivos fizeram você vir aqui na cidade de Guarapuava?

$R$ - Na verdade meu marido é comerciante e na época as coisas não estavam indo muito bem. Indicaram a cidade para ele. Era uma cidade com pouco comércio, na verdade pouquíssimas lojas e a gente veio e se acertou, se deu bem e adotamos a cidade.

A- Quem teria indicado?

$R$ - Na verdade foi parente e acabou pessoas acolheram muito bem aqui.

Esse movimento de dispersão pelo território do Paraná se deu em todas as direções, segundo Khodr (1987, p. 59), a cidade de Jacarezinho, no norte do Estado, foi fundada pelas famílias Abu e Jamara, assim como cidades do Estado de São Paulo, como Garça, Jaffa e Ourinhos.

\section{OS PRIMEIROS LIBANESES EM GUARAPUAVA PR.}

\footnotetext{
${ }^{1}$ Comerciante, descendente de libaneses, casada com um libanês, nasceu em Ponta, tem sua loja de vestuário localizada na rua Saldanha Marinho, mora em Guarapuava há mais de 30 anos.
} 
Nas pesquisas nos Acervos Históricos disponíveis em Guarapuava, encontramos documentos que comprovam a presença de libaneses (não de sírios, conforme já comentamos) desde, pelo menos, o ano de 1900. Alguns registros criminais da cidade de Guarapuava são reveladores dessa presença (Quadro 1).

Quadro 1- Registro criminal de Guarapuava em 1900.

\begin{tabular}{|c|c|c|c|c|c|}
\hline \multicolumn{2}{|c|}{900.2 .505} & Início: & 26.05 .1900 & ino: & 13.06.1900 \\
\hline \multicolumn{6}{|c|}{\begin{tabular}{l|l} 
Fundo: & Juízo de Direito da Comarca de Guarapuava
\end{tabular}} \\
\hline Local: Gua & Guarapuava & № Doc.: & \multicolumn{2}{|l|}{ № Caixa: 19} & № Pág.: 55 \\
\hline Autora: & \multicolumn{5}{|c|}{ Promotoria Pública } \\
\hline Réus): & \multicolumn{5}{|l|}{ Gabriel Caram } \\
\hline Vítima(s): & \multicolumn{5}{|c|}{ Amantino do Nascimento Rocha } \\
\hline Assunto: & \multicolumn{2}{|l|}{ Homicídio } & Tipo de Arma: & De $f$ & ggo \\
\hline Resumo: & \multicolumn{5}{|c|}{ Réu atira na vítima quando discutem na mesa de jogo, a vítima morre logo após } \\
\hline Conclusão: & \multicolumn{5}{|l|}{ Absolvido } \\
\hline \multicolumn{6}{|c|}{\begin{tabular}{l|l} 
Juiz: & João Capistrano de Araújo Ribeiro
\end{tabular}} \\
\hline Escrivão: & \multicolumn{5}{|c|}{ Francisco de Paula Alves } \\
\hline
\end{tabular}

Fonte: Acervo histórico da Universidade Estadual do Centro Oeste (UNICENTRO) consulta em setembro de 2011.

Este foi o primeiro registro que encontramos de pessoa com o sobrenome de origem árabe - Gabriel Caram - na cidade de Guarapuava, que evidencia a presença, mesmo que seja de passagem, de pessoas dessa procedência.

Também buscamos pelos nomes de origem árabe nos jornais da cidade, que circularam entre 1880 até 1930 , e no jornal O Pharol, de 1921, encontramos um anúncio comercial da loja do senhor Salim Abib, localizada na Rua Benjamin Constant. Notamos, ainda, que o antigo dono do estabelecimento também tinha origem árabe. Trata-se de Salim Tauile, dono da "Antiga Casa Moderna", que se constitui numa das primeiras materializações de estabelecimentos comerciais de origem "árabe" na cidade.

Neste mesmo jornal, encontramos ainda a relação de pessoas que recebiam telegramas na cidade e o nome de Felippe Karam aparece na relação de pessoas que utilizavam este meio de comunicação da época (Figura 1). 
No ano de 1930, era possível encontrar os descendentes de libaneses estudando em escolas tradicionais da cidade, como o colégio São José, que funcionava nos fundos da casa paroquial e oferecia 0 curso primário de $1^{\underline{a}}$ a $5^{\underline{a}}$ séries.

Segundo Teixeira (1993, p. 139), "em 1933 foi fundado o Síria Futebol Clube, uma agremiação que contava com destacados esportistas da colônia síria de nossa cidade, tendo como figura de proa Demétrio Akonoai e mais Gandur Abib, Salomão Abib, Nicolau Abicalaf, José Bitar e outros", sendo que todas esta pessoas citadas tem origem libanesa, mas apesar disso o time não era só composto por libaneses.

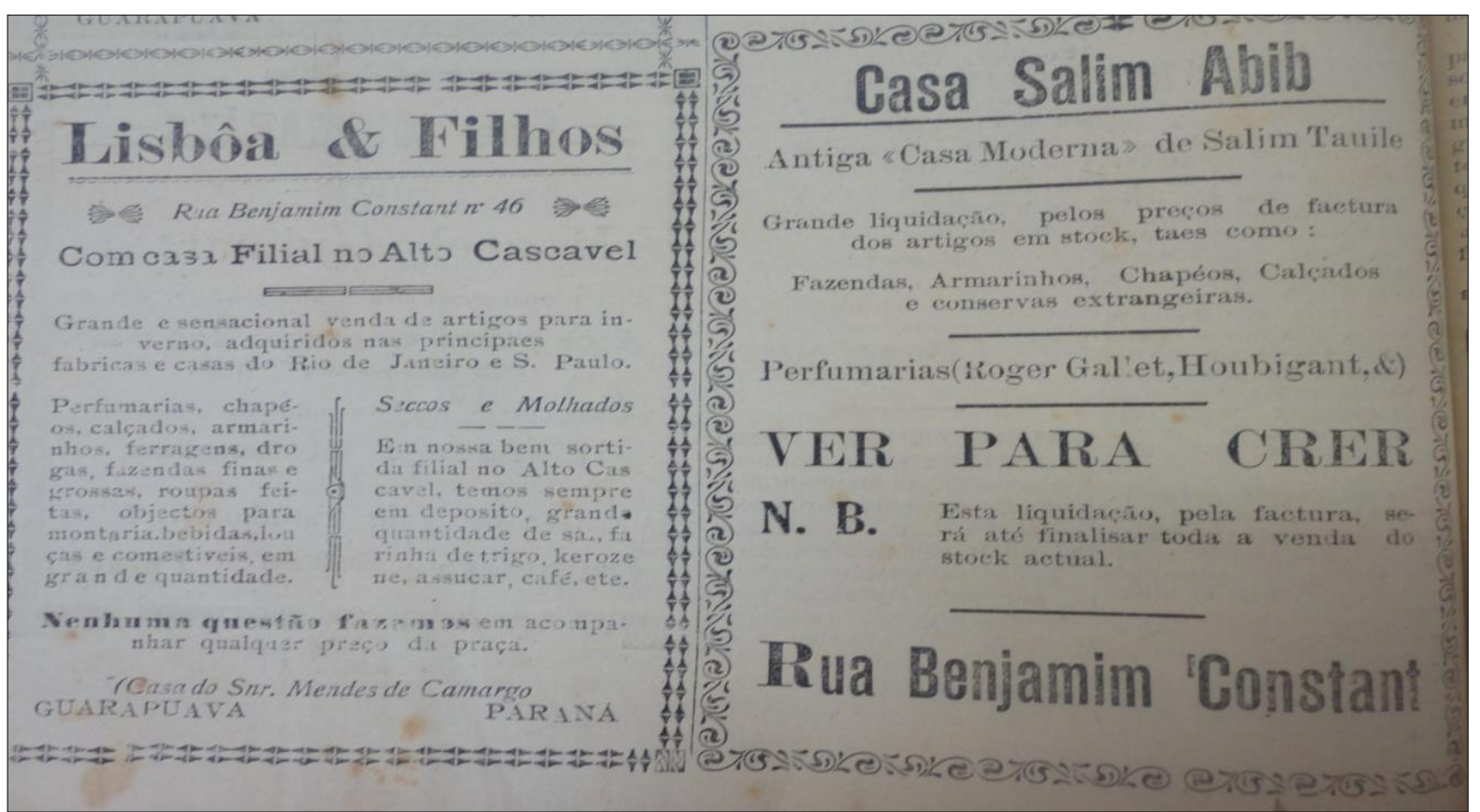

Figura 1 - Propaganda comercial de árabes no jornal O Pharol. Fonte: Acervo histórico da Universidade Estadual do Centro Oeste (UNICENTRO) consulta em setembro de 2011. Imagem trabalhada por Anderson Muzzolon.

$\mathrm{Na}$ foto 1, temos os componentes do time, alguns com sobrenomes de origem libanesa e outros não, seguindo na seguinte ordem, vemos em pé, da esquerda para a direita, Itália Manente Ribas (uma das madrinhas do time), Lírio Amaral, Cabo Honório Santos, Mário Amorim Knuppel, Atílio França, Renato Guedes, Saloa Abicalaf Cailôt (outra madrinha) e Demétrio Akaoni. Ajoelhados, na mesma ordem, João Ferreira, Deodoro Rosa e Romeu Polli. Sentados, Teodoro Ferreira, Ernesto Wagner e Juraci, ainda sentados em cima da bola o então garoto João Akaoni, filho de Demétrio Akaoni (TEIXEIRA, 1993). 
O nome "Síria Futebol Clube" se deu provavelmente em função do Líbano ainda não ter se firmado como um país independente e na data em que a foto foi tirada ainda era tratado como província da Síria, apesar de todos os sobrenomes citados serem de regiões que hoje pertencem ao território libanês, segundo o depoimento dos entrevistados e pesquisa na internet.

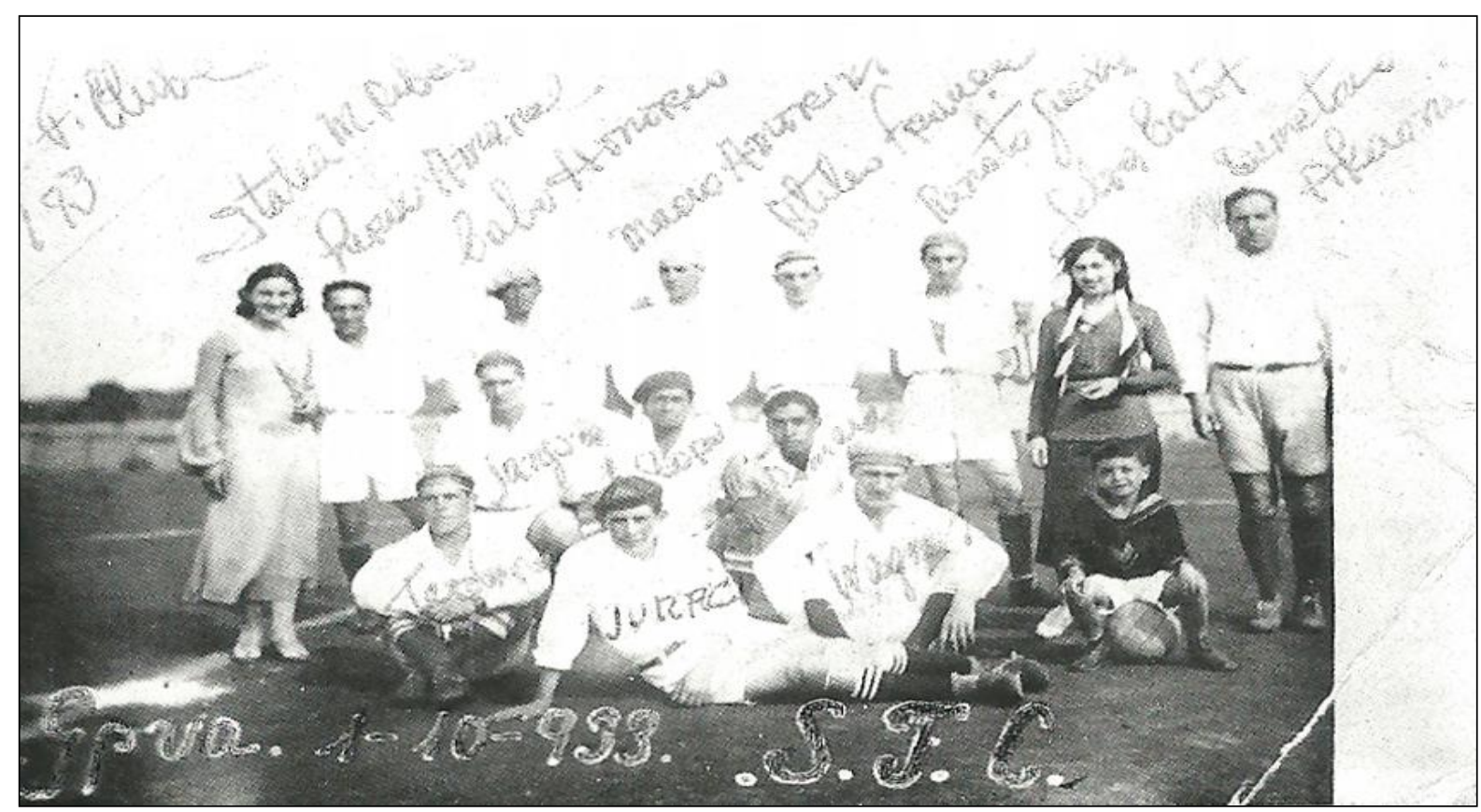

Foto 1 - Formação do Síria futebol Clube de Guarapuava, no ano de 1933. Fonte: Teixeira, L. C. (1993).

Os libaneses e seus descendentes, em Guarapuava, sempre estiveram envolvidos também com a política, auxiliando nas decisões que fizeram a cidade se constituir no que é hoje. Assim, encontramos registros que mostram que o primeiro vereador descendente de libaneses foi Fellipe Karam, primeiro da direita para esquerda (Foto 2), o qual exerceu dois mandatos consecutivos, de 1920 a 1924 e de 1924 a 1928. 


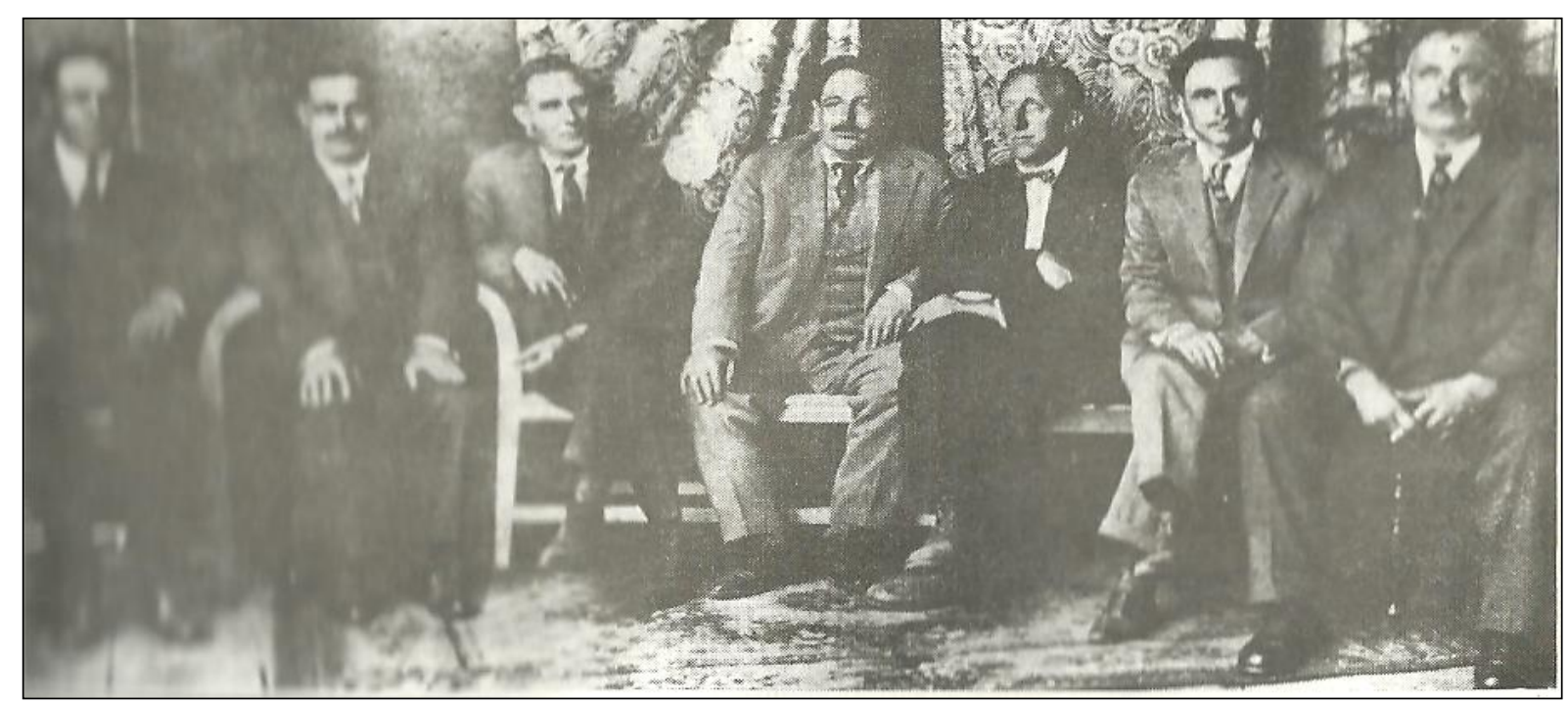

Foto 2- Vereadores de Guarapuava no ano de 1924. Fonte: Teixeira, L. C. (1993).

A tradição na política segue com vereadores como Emanuel Farah, eleito duas vezes na década de 1960 e, na década de 1970, entra na cena política a família Melhem, com o Dr. Abrão José Melhem, eleito duas vezes e também, em 1977, elege-se Elias Farah Neto. Em 1983, elege-se o vereador Dr. Élcio José Melhem, sendo reeleito em 1987 e atualmente é um dos vereadores de Guarapuava.

O número de famílias libanesas foi crescendo até a década de 1980, como percebemos no discurso de Jamil Darwich, que chegou à cidade na década de 1970. Ele afirma que, no final desta década, existia na cidade cerca de 70 famílias e, apesar disso, hoje esse número encontra-se reduzido, pois como ele disse boa parte das famílias deixou Guarapuava.

J- Na verdade essas setenta famílias não voltaram pro lugar de origem, eles esparramaram aqui no Brasil, eles estão uma parte em São Paulo, uma parte em Foz do Iguaçu, parte no Paraguai. É poucos que voltaram, porque raramente o libanês vai pra um lugar e fica nela pra sempre, nós temos libaneses aqui que tem propriedades em Guarapuava, que tão alugadas, e eles vem uma vez por ano, tá no nome das imobiliárias, eles vem uma vez por ano, e sempre eles vem aqui, dificilmente o libanês deixa o lugar que ele gosta, onde ele fez a vida, onde ele fez os contatos, a gente respeita muito essa parte.

Dessa forma, hoje, os representantes da imigração libanesa em Guarapuava têm seus membros reduzidos em função da busca por novas oportunidades em 
outras cidades e também em função dos descendentes não terem instituições que os façam afirmar a cultura libanesa. Essas oportunidades podem ser tanto na área do comércio, como da educação, uma vez que os libaneses, de uma forma geral, buscam sempre uma qualificação profissional na área da saúde, direito e engenharias, que ainda são deficientes em Guarapuava.

As relações sociais dos libaneses nos pareceram muito mais no sentido de integração com a sociedade local, do que de um fechamento em grupo. De modo geral, as tradições que ainda são preservadas estão muito mais ligadas ao núcleo familiar, do que na extensão para o grupo ou comunidade libanesa em Guarapuava.

Trata-se de um modelo de imigração diferente daquilo que imaginávamos de início. Pensávamos em modelos como o da imigração italiana, eslava ou germânica, em que em muitos casos era feita em colônias, as quais tinham incentivos do governo e formavam comunidades, onde se podia preservar os costumes de forma coletiva. O senhor Rames Nícolas Hosni nos fala como foram seus primeiros contatos com a sociedade local:

$R$ - Eu quando cheguei aqui em 1956, época de carnaval, "eu vou pra maracangaia eu vou", assim eu lembre, eu lembre (risos). Era música da época. Eu cheguei aqui, sabe como é que era, eu não falo nada, não sabe, ai diz que tem carnaval, não sei o que, não sei o que, peguei e fui no Clube Cruzeiro, e todo mundo dançando, e eu não falo, não sei (a língua portuguesa), ai as meninada sabe, quem eles gostam um que não sabe falar assim, e começaram a me pegar todo assim, e não terminou o carnaval comecei a falar o português, e sabe tem que entrar assim (fazer parte do grupo), é nunca aprende (sozinho não consegue aprender a língua) e começamos a brincar assim, todo mundo assim, e as sete horas chegou que as cinco horas da manhã, todo dia, vai aprender, todo mundo me pega, era novo né, era piazão.

Em um primeiro momento, buscamos identificar o grupo libanês como uma comunidade estruturada, com seus costumes compartilhados por um grande número de pessoas, mas essa ideia foi sendo desconstruída, na medida em que entrevistávamos essas pessoas. Essa falta de lideranças, ou de alguma agregação comunitária que mantenha os costumes fica bastante explícita no depoimento de Hamidi Omar Safadi Kasmas. 
A- $A$ vida social era feita e é feita em que contexto? Na familiar, na mesquita?

H- Aqui em Guarapuava, infelizmente, só no âmbito familiar. Só porque a gente não tem assim, a gente tem mesquita, mas não tem um xeique não, não tem. Então, a gente acaba não frequentando né, e acaba ficando na família mesmo.

$H$ - [...] eles são árabes libaneses também de origem né, mas eles vem de uma região do Líbano cristã e também tem isso entendeu, tem o libanês cristão e tem o libanês muçulmano, né. Você tá conversando comigo, que sou muçulmana sunita, não sou muçulmana xiita entendeu? Você vai conversar, por exemplo, meia quadra, vai chegar na esquina, é xiita entendeu. Mas todo mundo é libanês, a comunidade é a mesma.

Seguindo esse raciocínio, podemos identificar a territorialização de pelo menos três esferas de influência da religiosidade trazidas do Líbano: os muçulmanos xiita e sunita e o cristão (figura 2).

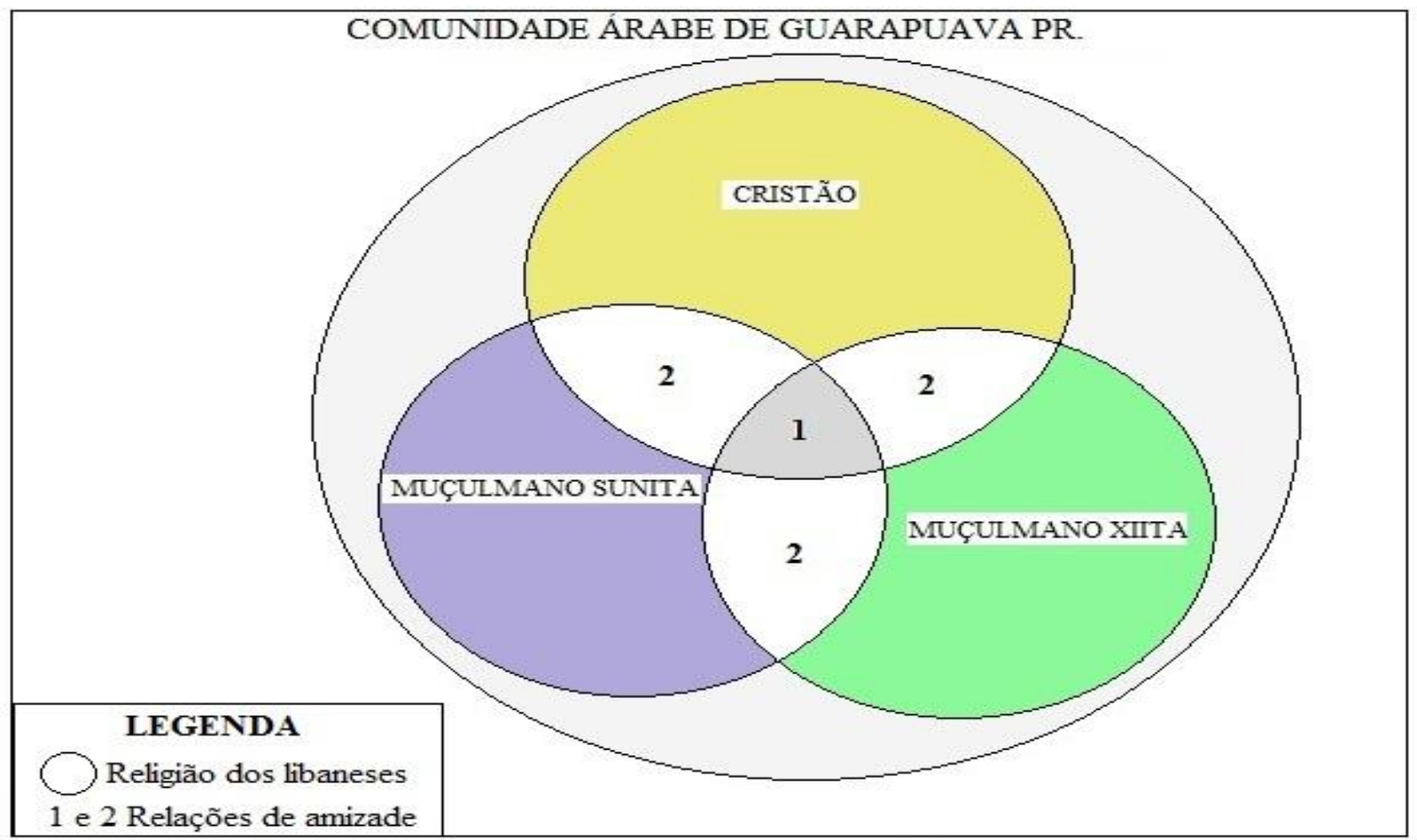

Figura 2- Representação da religião dos árabes que moram em Guarapuava. Elaborada por: Anderson Muzzolon, 2011, a partir dos depoimentos dos libaneses. 
Assim, percebemos que os imigrantes libaneses trazem as territorialidades e diferenças $^{2}$ que existiam no país de origem, as quais se materializam no espaço urbano de Guarapuava, apesar de neste territorializarem-se, em termos de atividade econômica, de forma concentrada, formando ruas comerciais reconhecidas "área de comércio popular turco".

No cruzamento dos depoimentos, conseguimos pensar nesta representação, na qual temos uma esfera geral, que representaria o fato de que todas as pessoas entrevistadas são libanesas e falam a mesma língua. No interior desta, temos três esferas menores, representando o tipo de religião que cada parte segue, como um divisor interno ao grupo, sendo as interseções 1 e 2 consideradas como relações de amizade e conhecimento entre esta pessoas.

Essa divisão, contudo, não permite uma vivência de comunidade mais articulada, gera conflitos que, às vezes, não são tão vistos por alguém de fora do grupo, que tendem a ver todos os libaneses de forma homogênea. No depoimento do senhor Rames Nicolas Hosni, percebemos mais algumas manifestações dessa diversidade, dos seus diálogos e conflitos e também mostra uma relação com a língua do país de origem, tendo certa dificuldade em conversar na língua portuguesa.

A- Que época foi esse clube árabe ${ }^{3}$ ?

$B$ - R-Faz uns cinco anos.

A- Hoje dá pra dizer que tem esses encontros?

$R$-É mais encontros pra conversar.

A- Familiar?

$R$ - É, não é isso, cada um cuida o que tem, não funciona.

A- Mas por que não funciona?

R- Não funciona porque cada um tem que puxar pro outro, esse negócio não serve, porque tem dois religião, a árabe, muçulmana e cristã, então não, não, não.

\footnotetext{
${ }^{2}$ Essas diferenças estão presentes no Líbano até hoje, as quais fazem com que o país tenha uma constituição específica, que busca manter a ordem entre estes três grupos religiosos na administração política do Estado libanês, que está estabelecido desta forma: o presidente do Líbano deve ser um cristão maronita. O primeiroministro, um muçulmano sunita, o Presidente da Assembléia Nacional deve ser xiita.

${ }^{3} \mathrm{O}$ clube árabe de Guarapuava foi uma tentativa de unir os libaneses na cidade formando, um ambiente em que fosse possível manter relações de amizades e preservar os costumes dos libaneses para as novas gerações.
} 
A- O senhor acha que o peso religioso é forte nessa questão?

$R$ - É. Não é forte (a união de todos).

A- Para não dar certo?

$R$ - É, é, a mesquita, muçulmanos. Mas nós não vamos, e por nós somos católicos. $E$ eles são... E não funcionou também, porque tem pouca gente.

Nota-se que, quando chegaram ao Brasil, os imigrantes árabes, assim como membros de outras etnias, que optaram pelo país como destino, trouxeram consigo, em alguma medida, as tensões do território originário. Os árabes, marcados por elementos identitários de ordem familiar, social e religiosa, carregaram em sua bagagem estas diferenças, que podem ter permanecido fortes por algum tempo entre eles, e que afloraram em determinados momentos, como nos depoimentos que coletamos.

A primeira rua onde os libaneses começaram a concentrar-se foi a Saldanha Marinho(ver mapa 1), o local servia como uma das portas de entrada para as pessoas que vinham fazer compras na cidade, dada sua proximidade com um antigo ponto de ônibus da viação que percorria as várias cidades da região, entre as décadas de 1950 e 60.

A- Tinha mais gente que hoje (na comunidade libanesa)?

$H$ - É, tinha mais gente que hoje, hoje tem os netos, filhos, muita gente morreu, se mudou, mas tinha mais gente do que hoje. Pro senhor ter uma idéia, na década de setenta, setenta e pouco, hoje Guarapuava soma só a cidade em torno de 150 mil, a cidade né, só a cidade, na época, média de 70 mil pessoas, na década de 1970, 75, tinham cerca de 35, 36 lojas aqui, hoje se tiver 19, 20 lojas não sei se tem.

Com base nestes depoimentos, chegamos à conclusão que a territorialização libanesa em Guarapuava está intimamente ligada com as variações que se deram no espaço urbano e com a dinâmica do mercado regional. 


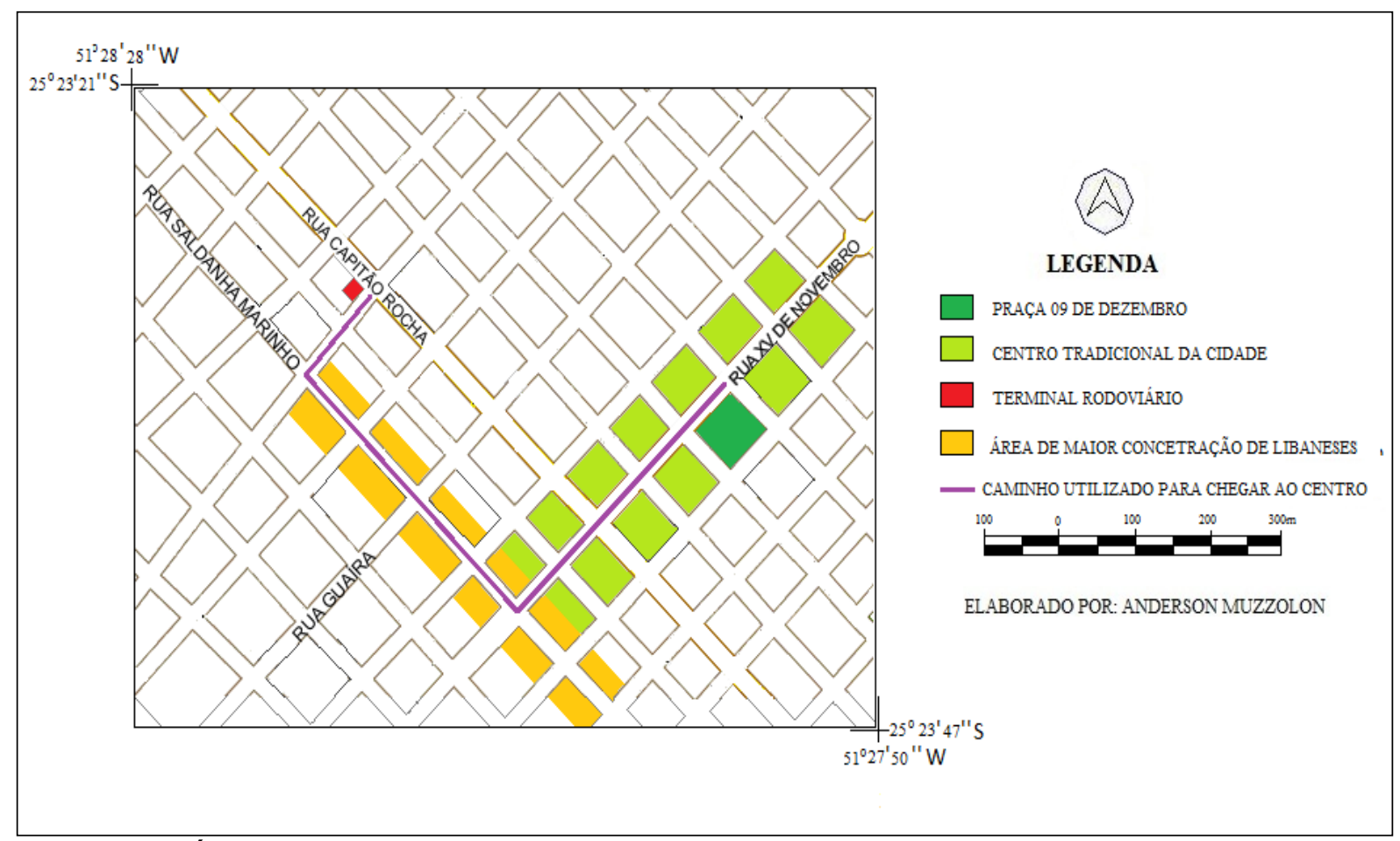

Mapa 1 - Áreas de territorialização libanesa nas décadas de 1950-60. Elaborado por Anderson Muzzolon, 2011. A partir do mapa base da Prefeitura Municipal de Guarapuava.

A localização dos primeiros pontos onde paravam os ônibus, que traziam pessoas de fora, vistas como clientes cativados nos tempos da mascateação, era um fator importante na escolha de onde se abrir a loja (ver mapa 1). As pessoas de um modo geral passavam por esse espaço, para chegar ao centro tradicional da cidade e fazer usos dos serviços que este local oferecia.

Com o passar do tempo, nas décadas de 1970 e 1980, o terminal rodoviário mudou de lugar (que na verdade não era um terminal rodoviário oficial, era um local onde costumeiramente os ônibus paravam), passando, então, a se localizar mais próximo ao centro tradicional da cidade (ver mapa 2), onde hoje se localiza o atual terminal de ônibus urbanos, denominado Estação da Fonte. Nesse momento, a Rua Guaíra ganhou destaque para os interesses dos libaneses. 


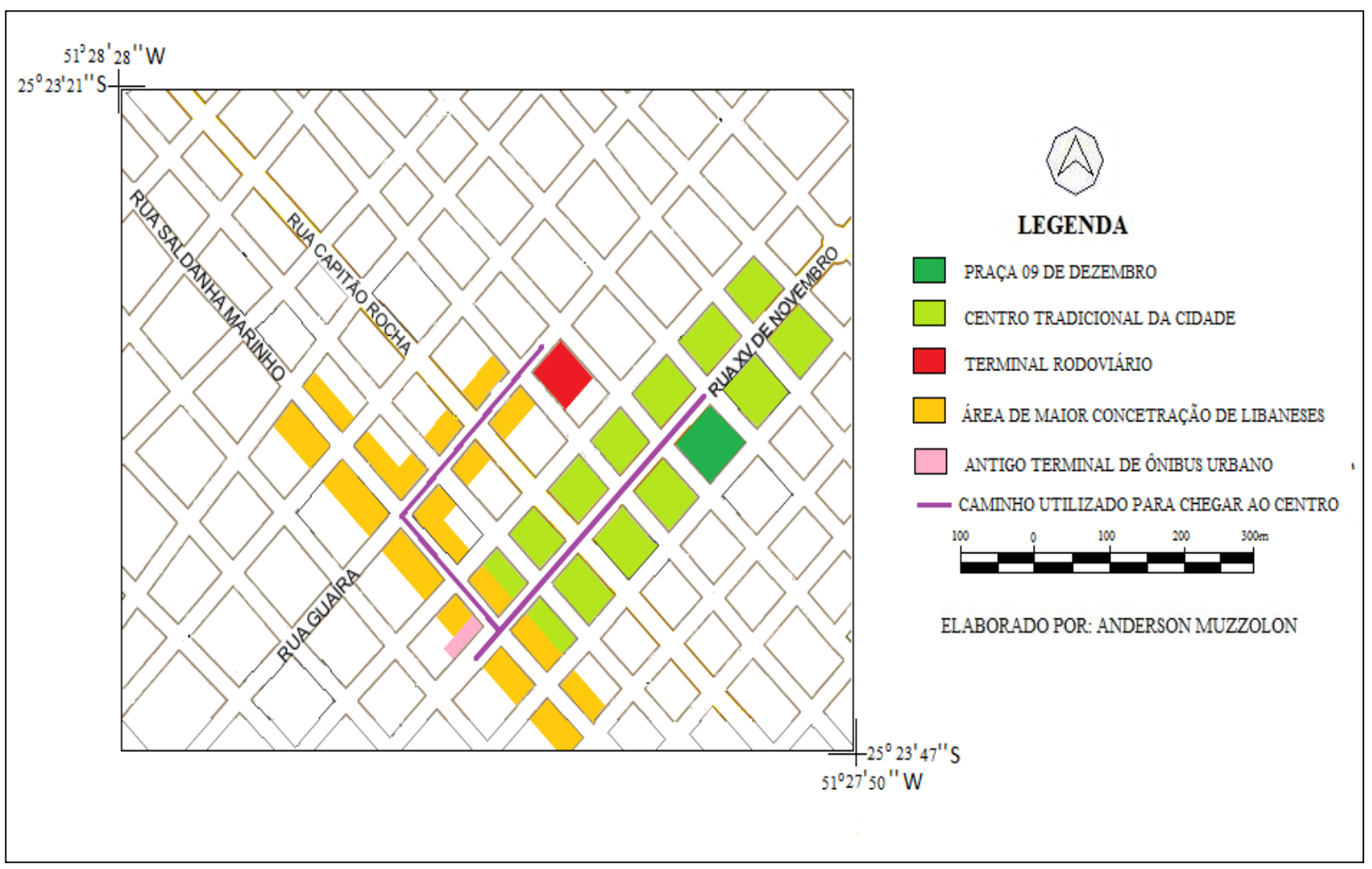

Mapa 2 - A territorialização libanesa nas décadas de 1970-80. Elaborado por Anderson Muzzolon, 2011. A partir do mapa base da prefeitura Municipal de Guarapuava.

O fluxo de pessoas agora busca as duas principais ruas comerciais da cidade. A XV de Novembro e também a Saldanha Marinho, que se firma como rua comercial com força também. A caminho dessa última, chegando pela nova Rodoviária, passava-se, necessariamente, pela Rua Guaíra.

Na década de 1990, a rodoviária da cidade é novamente transferida de lugar. Agora passa a localizar-se no Bairro Bonsucesso. Esse fato contribuiu para a diminuição daquilo que Rita Reda chamava de "comércio com os fazendeiros", em que parte das pessoas cativadas na mascateação chegava à cidade pela rodoviária e dali se dirigia caminhando pelas referidas ruas.

Outro fator que representou mudanças na dinâmica dos territórios conquistados pela atividade comercial libanesa se deu em função da própria cidade mostrar um grande crescimento urbano nas últimas quatro décadas, dado principalmente pela saída das pessoas do campo. Fato que veio a reforçar a centralidade do comércio urbano e do centro principal, tanto para a mais ampla população urbana de Guarapuava, quanto para as outras cidades da região e também da zona rural. Tal fato é responsável também pela ampliação de atividades 
comerciais e de serviços situadas no centro, inclusive com presença de filiais de lojas de departamentos que atuam em escala nacional e regional, bem como pela expansão da área do centro principal em direção às ruas Guaíra e Saldanha Marinho, atraída pela presença anterior do comércio popular libanês (Mapa 3).

Assim o centro ganha maior valor comercial, fazendo com que os libaneses mantenham em parte seus estabelecimentos nos locais onde anteriormente tinham se estabelecido. Os estabelecimentos pertencentes a libaneses e seus descendentes, hoje, não são mais exclusivamente comerciais, mas, com a formação das novas gerações em algumas profissões liberais (como médicos e advogados), alguns vieram instalar seus escritórios também no centro de Guarapuava, acompanhando o movimento de territorialização anterior. Um fato interessante perceptível no mapa, é que a rua XV de Novembro (rua de cima) ainda não tem estabelecimentos ou propriedades de libaneses, ficando de fato a preferência por se estabelecerem em suas adjacências.

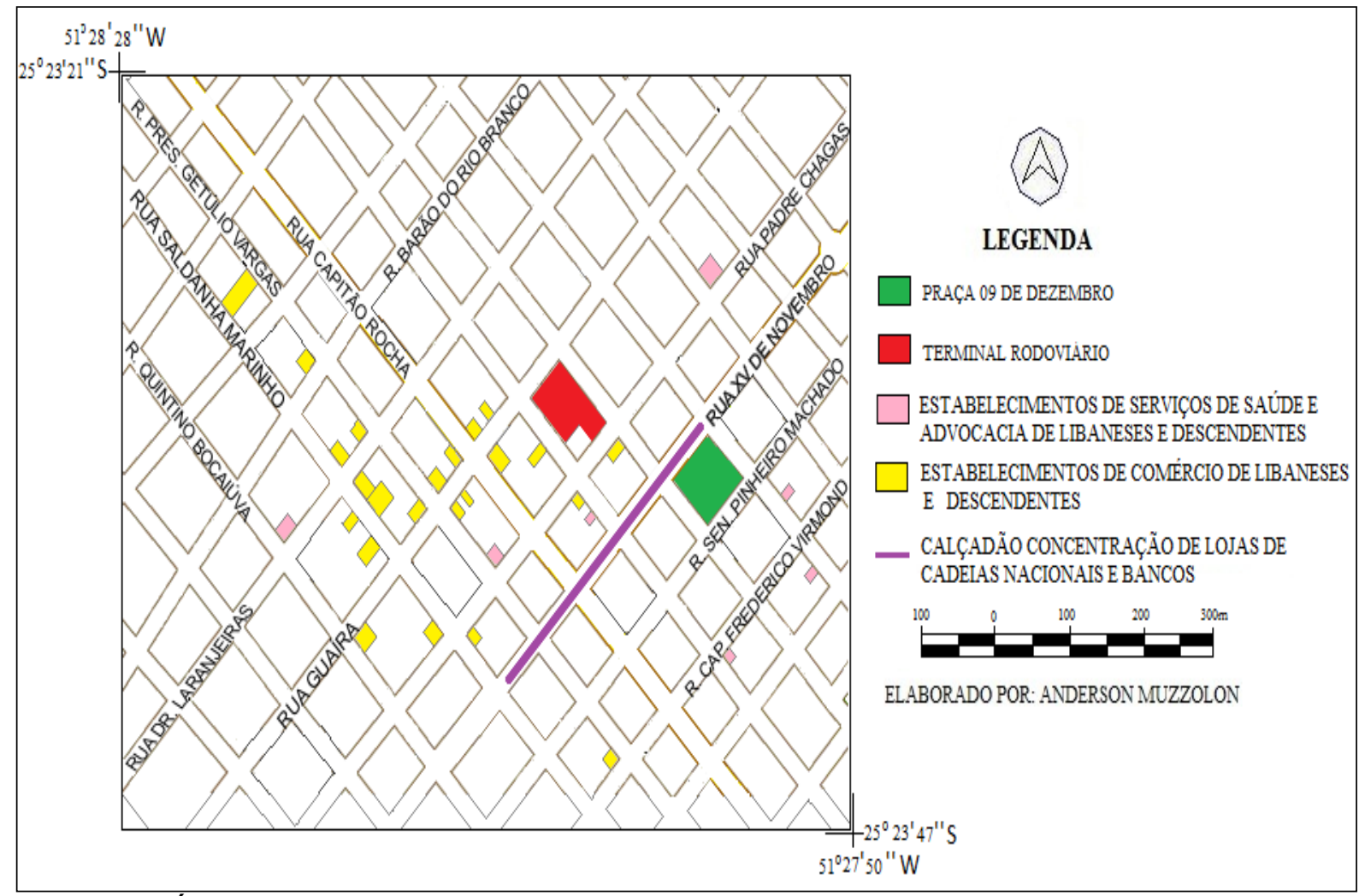

Mapa 3 - Áreas de territorialização de libaneses e descendentes em 2012. Elaborado por Anderson Muzzolon, 2011. A partir do mapa base da prefeitura Municipal de Guarapuava. 


\section{CONSIDERAÇÕES SOBRE O TERRITÓRIO DOS LIBANESES E A CONSTRUÇÃO DO LUGAR.}

Partimos do pressuposto de que no universo em que vivemos nada se manifesta de forma igual, assim ao trabalhar com o território enquanto conceito de análise espacial, cada sujeito da territorialização poderá nos conduzir a um tipo de território e a uma dinâmica territorial diversa (HAESBAERT, 2009)

Desse modo, na pesquisa, o ponto de partida não foi o território, enquanto um espaço já dado na paisagem, mas os sujeitos sociais que, pelas relações de poder projetadas espacialmente, territorializaram-se de certa forma.

Assim, para compreender parte da construção do espaço urbano a que nos propomos nesta pesquisa, buscamos não apenas nos atermos às formas que se materializaram neste espaço, mas considerar sobretudo o entendimento de como os sujeitos que o constroem se articulam e fazem com que aquelas formas se deem daquela maneira e sejam carregadas de simbologias.

Verificamos que os processos de produção dos diferentes tipos de territórios resultam não apenas de mudanças estruturais nos campos econômico e político, nos plano global e local, mas também de mudanças no campo da subjetividade. De modo geral, os indivíduos buscam o novo, possibilidades diferentes, novas relações, resultando em um processo constante que cria um movimento que Haesbaert (2009), chama de des-re-territorialização.

Mas não necessariamente apenas as mudanças são importantes para a construção dos territórios, as permanências também fazem parte da busca que das por dominar certas áreas para melhor sobreviver. Assim, os libaneses, ao adquirirem algum capital, buscaram propriedades em locais com potencialidades para 0 comércio e que, sobretudo, Ihes fossem acessível, diante dos recursos que dispunham. Dessa forma, de início, estabeleceram-se em ruas com pouca estrutura e fora da área central da cidade. Mas com sua permanência e a ampliação desses espaços durante mais de meio século, foi possível ver a transformação destas ruas em espaços altamente valorizados por quem se dedique a atividade comercial na cidade de Guarapuava. 
Em entrevista com o senhor Rames Nicolas $\mathrm{Hosni}^{4}$, ele fala como era a relação dele com a cidade de Guarapuava e os moradores daqui, quando chegou à cidade. Verificamos que a atividade comercial contribuiu para o não fechamento em grupo, mas a inserção dessas pessoas no local onde vivem, como aprender a língua local, era uma necessidade, pois precisavam estabelecer relações de amizade, a fim de desenvolver a atividade comercial:

A- Como era a cidade quando o senhor veio pra cá?

R-Guarapuava era uma vila pequena, 1956, uma vila.

A- E já tinha algum conhecido aqui nessa época?

$R$ - Não, nessa época não tinha, nós abrimos lojinha e começamos a trabalhar.

A- Abriram a loja aqui mesmo na Saldanha Marinho (rua)?

$R$ - Nessa rua mesmo, não saí desta.

A- A cidade ia muito mais além desta rua?

R- Não. Eu caçava perdiz, codorna ali ao lado (risos), era mato, campo, caçava, nossa!

A- A relação com as pessoas como era?

$R$ - Sabe como é que é, quem abre loja, vem um cliente, vem um freguês, vêm amigos, vai conhecendo todo mundo.

Se o território é "um espaço definido e delimitado por e a partir de relações de poder" conforme os termos de Souza (2001), verificamos que, ao longo da materialização dos libaneses no centro da cidade, estes não se colocaram como ameaça de poder econômica ou cultural aos habitantes desse lugar (talvez em função de serem minoria e de dependerem dessa população, enquanto mercado consumidor, para sua sobrevivência). Sua participação nas mais variadas instâncias de poder local foi sendo construída aos poucos, modesta e individualmente, por alguns libaneses que nunca se colocavam, pelo menos não publica e explicitamente, como representantes deste grupo econômico e cultural.

Desse modo, verificamos que a família sempre teve papel importante neste processo, os pais ou irmão dos libaneses viam a possibilidade de continuidade da família, na saída de um de seus membros, indo para lugares em que não thes

\footnotetext{
${ }^{4}$ Empresário, cristão, trabalha como comerciante em sua loja Jamel Jeans, localizada na Rua Saldanha Marinho, chegou em Guarapuava em 1956.
} 
parecesse hostil e que abrisse novas possibilidades. Assim, se por um motivo ou por outro seus descendentes decaíssem no local de origem, abria-se a possibilidade de levar adiante o nome da família em outros lugares.

Esse esforço é percebido nos depoimentos, que mostram a determinação dos familiares em pagar a passagem de travessia do Atlântico para se chegar a um local onde se thes parecia ter maiores possibilidades, nunca vindo toda a família, mas parte ficando no Líbano, existindo vínculos permanentes entre o que saiu e o que ficou, vínculos estes que sempre o chamam para o retorno, o qual é acalmado por meio de visitas, ou por meio de comunicações que variaram de fitas gravadas, até conversas online nos dias de hoje.

A oportunidade de fazer dinheiro em relativamente pouco tempo e numa quantia superior a média local exerceu influência na ação de sair das aldeias libanesas. Logo, as famílias passaram a planejar o envio de seus filhos, inicialmente de forma temporária, como forma de resolver suas dificuldades financeiras. O que era temporário, em muitos casos, tornou-se permanente, pois ao chegar a um país estrangeiro, os "patrícios" além de conseguirem dinheiro, conseguiram criar novas famílias, o que tornou difícil a volta ao país de origem.

Os referenciais dos primeiros emigrantes, que são mostrados para os libaneses, são o de sucesso econômico de alguns de seus amigos, tios, pais ou irmãos no Brasil, assim cria-se uma imagem de país que tem o povo amigável ao libanês, com grandes extensões de terra (assim muitas cidades e localidades para negociar) e a possibilidade de acumular algum capital e começar empreendimentos maiores.

No plano econômico, o Líbano mostrava poucas possibilidades em função das dimensões do país e de anos de exploração, causados por sua submissão e tributos a outros países dominadores. Os que emigraram estavam se dedicando, no Líbano, a atividades que não Ihes garantia ganhos expressivos, como a agricultura em pequenas propriedades. No novo país, buscaram melhorar sua condição financeira trabalhando com o comércio.

As ameaças externas ao povo libanês sempre foram uma constante. Diferentes nações que foram dominantes belicamente durante a história da humanidade, entraram em conflito na região, gerando uma grande diversidade de 
ideais internos e, em consequência disto, disputas de poder entre vários grupos culturais, causando sérios conflitos entre os próprios libaneses e a sensação de insegurança que em parte serviu de motor para se buscar nações mais estáveis.

Estes fatores internos potencializaram a emigração, as diferentes manifestações religiosas, diferentes culturas fazem com que o Líbano seja formado por uma multiplicidade de territórios, muitos dos quais disputados, inclusive belicamente.

Nos depoimentos são perceptíveis que todas essas variantes tiveram importância na hora de decidir sair do Líbano, assim um motivo ou outro, ou talvez todos em conjunto, de certa forma, fizeram com que o Líbano fosse país de emigração e os libaneses um povo em diáspora, em busca de construir um novo território-lugar em outros cantos do mundo.

A transposição do território de origem, para o território de chegada, ou a reterritorialização, nos termos de Haesbaert (2009) exigiu adaptações. Sua cultura, seus valores, suas práticas não seriam mais vivenciados da mesma maneira. A partir do momento em que os libaneses foram introduzidos num ambiente sociocultural diferente, negociações tornaram-se obrigatórias, seja com a sociedade local, seja com os próprios patrícios.

Quando o imigrante chega a um novo lugar, os desafios são enormes. No caso do Brasil, tiveram que aprender uma nova língua, adentrar em terrenos desconhecidos, mostrarem-se como amigos e não como ameaça a sociedade estabelecida, dedicarem-se a atividades (mascateação) que a principio não ofereciam concorrência com aquelas dos nativos, pelo contrário, servindo de elo entre um povoado e outro.

Essas pessoas retêm fortes vínculos com seus lugares de origem e suas tradições, mas sem a ilusão de um retorno ao passado. Elas foram obrigadas a negociar com as novas culturas com que passaram a conviver, sem simplesmente serem assimiladas por elas e sem perder completamente suas identidades. Elas carregam ainda hoje os traços das culturas, tradições, linguagens e das histórias particulares pelas quais foram marcadas, assim não pertencem a um lugar, mas a vários, formando assim um hibrido cultural conforme abordagem de Bhabha (1998). 
A imigração, em razão das múltiplas variáveis que a envolvem, revela-se como processo de desestabilização das identidades centralizadas e dos lugares que se afirmam homogeneizados, principalmente quando se trata de um povo como o libanês, que tem sua constituição cultural bastante heterogênea, que promove a mudança nos locais onde se estabelece.

Cada vez mais, as grandes verdades de fortes discursos que constroem os lugares são colocadas à prova, visto que as afirmações que pregam a identidade única de cada lugar são tecidas com base em visões que negligenciam a heterogeneidade dos sujeitos e grupos que compõem a sociedade (Massey, 2000).

Nessa perspectiva de mudança recíproca, manter os costumes na família não foi tarefa fácil para pessoas que chegaram e ficaram circunscritas em uma sociedade que tem valores diferentes dos seus, nas escolas não se ensina o árabe, nem as religiões praticadas inicialmente no Líbano, os clubes, associações e a própria mesquita (Foto 03) não funcionam, em função dos referenciais culturais trazidos pelos libaneses serem eles próprios múltiplos.

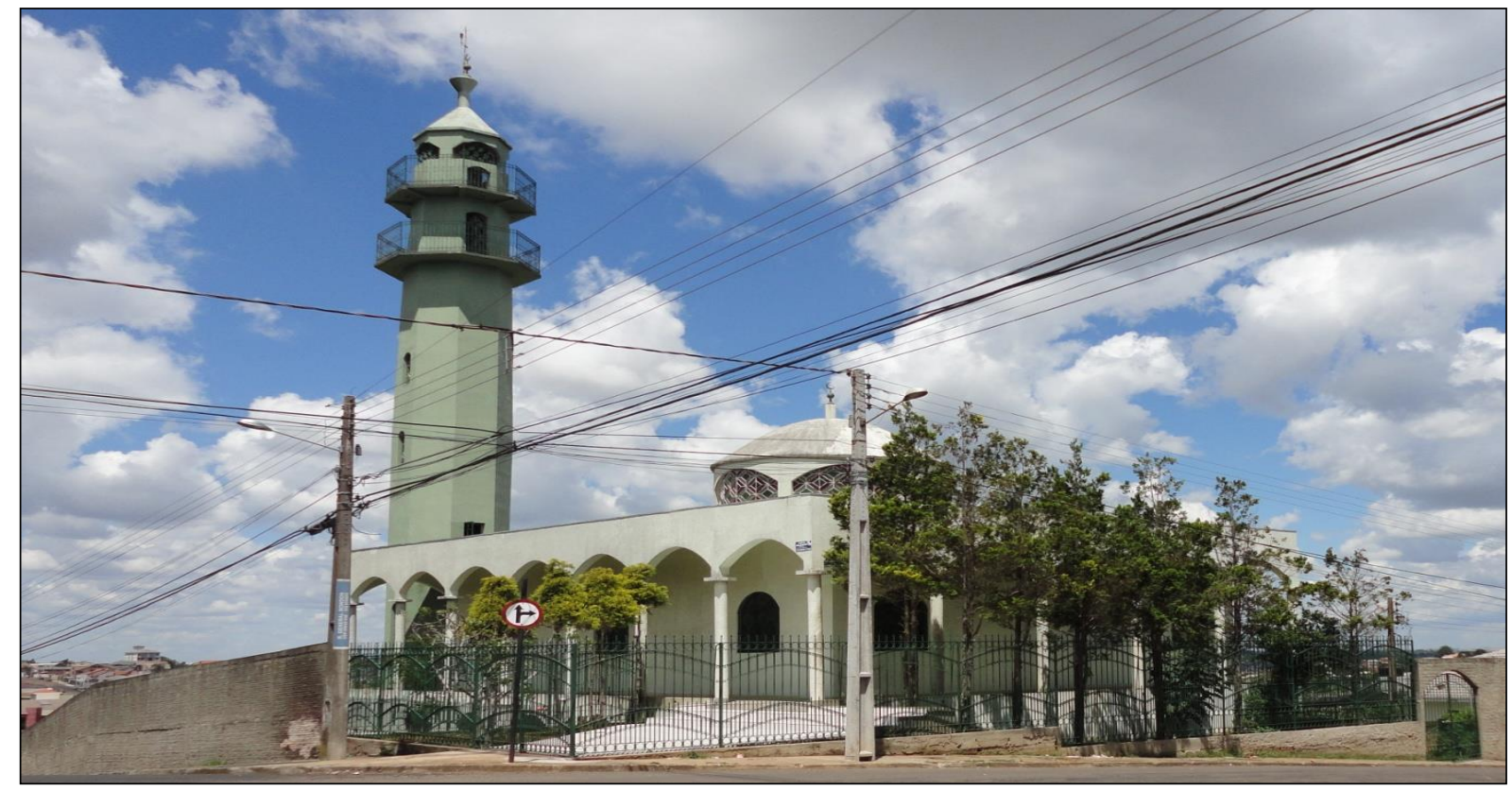

Foto 3 - Mesquita de Guarapuava esquina das ruas Beijamim Constant com General Rondom.Foto: Anderson Muzzolon (2012).

A transmissão desses valores fica por conta da família. Em alguns casos percebemos haver uma preocupação com isso, mas em outros não, conforme 0 depoimento de Hamidi Omar Safadi Kasmas: 
$H$ - Eu acho que sabe se nos tivéssemos um líder religioso aqui, um xeique, alguma coisa mais voltada para os nossos filhos, numa questão religiosa, acho que serviria como um elo sabe, que é assim na comunidade islâmica; não sei bem porque não tenho essa experiência para te contar mais a nossa comunidade, religião, ela segura muitos aspectos da família entendeu, e outra coisa, o árabe, na religião, ela é diretamente ligada ao direito, entende, porque aqui não é, aqui é muito separado a lei, a religião, a religião lá não. Lá, muita lei vem da religião entendeu. Lá é muito ligado.

De certo modo, existe uma tendência dos descendentes de libaneses se pulverizarem pela sociedade e na segunda ou terceira geração fica apenas o referencial do sobrenome como indicativo de ascendência daquele país.

$\mathrm{Na}$ medida em que o tempo passa, novas relações surgem, nascem os filhos de imigrantes, algumas referências ficam, outras caem no esquecimento. Verificamos que a primeira geração busca muito mais uma integração a sociedade local do que a manutenção da cultura de seus antepassados, de modo geral tendendo a apagar as referências libanesas, pois trata-se de um grupo que encontra-se em minoria em relação a comunidade local e com poucas instituições que preservam elementos culturais do Líbano.

Desse modo, podemos afirmar que no movimento da imigração libanesa, as variantes do território são múltiplas, suas relações com o seu lugar de origem são afrouxadas, porém não são exterminadas, e muitas dessas relações vividas influenciam hoje nas construções de novos territórios aqui. Essa experiência de se vivenciar ao mesmo tempo lugares diferentes, pelo pertencimento que se tem a diferentes grupos, ou por suas conexões em diversas escalas é que dão a cara dos novos territórios.

Na literatura pesquisada, com Haesbaert (2009) e Souza (2001), percebemos algumas variantes de territórios que se articulam em áreas contínuas e que às vezes se espacializam, a partir destas, em forma de rede, assim ampliando áreas de influências e se articulando de uma forma descontínua no espaço.

Em nosso caso de estudo, podemos perceber uma relação diferente entre território contínuo e descontínuo. Primeiramente, constatamos a formação territorial de uma rede mundial de emigração, formada por diferentes pontos e vetores, 
articulados por um grande número de lugares no mundo, e que acabaram se materializando no espaço urbano de Guarapuava, formando um território areal contínuo neste espaço urbano. Portanto, partindo da organização em rede para a formação de uma área.

Os rótulos que acompanharam os imigrantes de diversas nacionalidades, como "turco", no caso dos imigrantes de origem árabe, tem a finalidade de agregar os indivíduos oriundos de outros países sob a ótica da exclusão. Na realidade, esses termos lançavam sobre os estrangeiros um estigma generalizante. No caso dos libaneses, embora sendo reconhecidamente herdeiros de uma vasta herança cultural, a sua ocupação principal em terras brasileiras, o ofício de mascate, rendeuIhes a fama de negociantes sovinas, obcecados pelo lucro. Aquilo que se chama de "turco" é um artefato das pessoas estabelecidas e que se identificam como brasileiro ou Guarapuavano, julgando-se diferentes em identidade do libanês, mas como se tivessem uma identidade única e coesa.

Ao mesmo tempo em que se tem essa repulsa, digamos sutil, temos por outro lado um olhar de admiração, pois no pensamento popular, criam-se as questões de como os "turcos" chegaram sem nenhum dinheiro e hoje possuem vários empreendimentos em áreas de grande valor imobiliário do centro urbano da cidade.

$\mathrm{Na}$ literatura, temos os casos que mostram como as pessoas mais pobres, sofrem pressão para sair de áreas mais próximas ao centro (pressão das imobiliárias e IPTU) e migrarem para áreas mais afastadas, vendendo suas propriedades para as famílias mais ricas da cidade, o que não foi o caso dos libaneses, que adquiriram suas propriedades em áreas menos valorizadas e, pela atividade comercial que desenvolveram, criaram uma centralidade que desenvolveu estas áreas, atraindo a expansão do centro nesta direção, ao mesmo tempo que se capitalizaram e conseguiram se manter nela até hoje, e aquilo que outrora tinha pouco valor imobiliário hoje se inverteu.

\section{A NEGOCIAÇÃO DAS IDENTIDADES E A FORMAÇÃO DO LUGAR.}

O libanês sempre se mostrou determinado em construir seus empreendimentos, demarcando seu território, na busca de inserção na sociedade 
local, buscando a participação plena na construção do seu novo lugar de vivência, com certas referências tiradas das interações com os estabelecidos.

Nesse sentido, concordamos com Bhabha (1998, p.77), quando afirma que "a questão da identificação nunca é uma afirmação de uma identidade pré-dada, nunca uma profecia autocumpridora - é sempre a produção de uma imagem de identidade e a transformação do sujeito ao assumir aquela imagem - isto é, ser para um Outro". O jogo que se dá na identidade não se apresenta com algo dado, ou acabado, ele se mostra como uma busca constante das pessoas por elementos que thes são apresentados e que são assimilados ou refutados, dependendo de cada sujeito. Em função disso, podemos afirmar que o lugar e os territórios que os libaneses constroem aqui são únicos, formado por essa relação de mão dupla entre eles e a sociedade estabelecida.

$\mathrm{Na}$ medida em que imigrantes (e não somente eles, mas todas as referências de um mundo em processo de globalização) chegam à sociedade local, os sistemas de significação cultural se multiplicam. É possível verificar a territorialização de uma multiplicidade de possibilidades de identificação, que multiplicam também os territórios, pluralizam a experiência territorial, ao mesmo tempo em que complexificam o lugar.

Buscamos uma visão dos sujeitos sobre si mesmos, sobre a sociedade da qual passaram a fazer parte e do lugar que ajudaram a construir, percebemos que novas relações territoriais aparecem, todas as diversidades culturais dos libaneses surgem em seus discursos, bem como as diferentes formas com que cada um se relaciona com os demais. Os espaços que são frequentados dependem, por exemplo, da sua religião. Os sujeitos estudados "são formados e modificados num diálogo contínuo com mundos culturais exteriores e as identidades que estes mundos oferecem" (HALL, 1999, p. 11).

De certo modo, os libaneses trazem consigo elementos uma identidade nacional que pode ser pensada como unívoca, como, por exemplo, o fato de serem do mesmo país, de falarem a mesma língua e de serem imigrantes em um novo país. Fato este que poderia fazer com que, em certas circunstâncias, atuassem de forma articulada. 
Hall (1999, p. 47) afirma que "no mundo moderno, as culturas nacionais em que nascemos se constitui em uma das principais fontes de identidades". Mesmo entre os imigrantes libaneses, que apresentam tantas diversidades entre si, eles vêem no Líbano, enquanto nação, um elemento de união, sobretudo em um novo contexto em que se apresentam como cultura subordinada (na chegada a um lugar em que representam uma minoria) no qual se faz urgente uma conexão entre os que vieram, criando uma nação imaginada em que por momentos se esquece das velhas rixas. Talvez este seja elemento importante para entender o porquê da localização de forma coesa no espaço urbano de estabelecimentos comerciais de libaneses tão diferentes.

Podemos afirmar, não sem riscos que, como membro dessa comunidade imaginada, os libaneses se veem como compartilhantes de uma narrativa comum. Esta ideia "dá significado e importância a nossas monótona existência, conectando nossas vidas cotidianas com um destino nacional que preexiste a nós e continua existindo após nossa morte" (HALL, 1999, p. 52).

Por outro lado, há elementos identitários que particularizam os libaneses e os diferenciam entre $\mathrm{si}$, como a religiosidade, o local de origem da família, suas relações com as pessoas que fazem parte de sua vida, de modo que a articulação a uma comunidade nacional imaginada - formando uma comunidade libanesa num outro país - é sempre parcial e a estruturação de sua identidade permanece aberta.

$O$ fato de eles serem sempre minoria nos locais onde vivem nos parece, pelo menos em seus discursos, que fazem com que as diferenças originárias do Líbano não aflorem no local, pois todos declaram ter boas relações com os patrícios, independente de sua religiosidade ou posicionamento político. Assim, reafirma-se a identidade nacional, ou seja, os libaneses, com todas as suas diferenças, acabam se unindo como um povo só, não havendo uma segregação entre eles quanto se territorializam em Guarapuava.

Esse movimento desarticula algumas identidades do passado que pareciam estáveis, abrindo a possibilidade para novas articulações para os sujeitos, e estas, por sua vez, os tornam novos sujeitos, agora com novas experiências, novos conflitos, novas sabedorias. Aquilo que era divinamente - e, no caso dos libaneses também politicamente - estabelecido, hoje está sob o signo da mudança. 
Apesar disso, verificamos que fica impossibilitada a formação de clubes árabes ou associações onde todos possam participar, pois aí afloram as diferenças culturais trazidas de suas territorialidades no país de origem, pois na formação desses grupos teria que se escolher algumas referências culturais que seriam retransmitidas para o grupo e as futuras gerações, mas a escolha de um ou outro elemento cultural iria contra a história de vida de outros membros. Então, a união entre os libaneses no Brasil, de certa forma, encontra barreiras na religião que praticam, mas sobretudo, nos conflitos religiosos que viveram no Líbano e que continuam acesos por lá.

Após extensa pesquisa, verificamos que não há fontes que indiquem ou estimem o número de imigrantes libaneses na cidade, as quantificações ficam por parte da memória dos libaneses que afirmam que, nas décadas de 1970 e 1980 as famílias variavam de 70 a 80 , a maioria vinculada ao comércio, no centro da cidade.

O principal fator de integração entre os libaneses e a cidade receptora foi a atividade comercial, exercida por todos os imigrantes libaneses que chegaram a Guarapuava (pelo menos de início). A opção por esse tipo de atividade pode ser explicada, segundo os colaboradores da pesquisa, pelo fato de permitir maior flexibilidade no cotidiano e demandar pouca estrutura para o trabalho - visto que de início, se estabelecia como mascate. A atividade comercial teve um papel definitivo da integração com a comunidade estabelecida.

Em muitas lojas que visitamos, são as mulheres que estão atuando na venda e administração do empreendimento, com o auxílio do marido, o qual tem maior flexibilidade para viajar e até mesmo visitar os parentes no Líbano, enquanto que a mulher fica cuidando dos negócios. Isso mostra como o universo feminino ganhou expressividade na conciliação entre o trabalho, compromissos domésticos e educação dos filhos.

Trata-se de assimilação de valores ocidentais, em que a mulher deve participar do mercado de trabalho. Em todas as entrevistas percebemos que a educação que os pais têm dado as suas filhas é com vistas a terem uma formação acadêmica que Ihes garanta um trabalho nas áreas de advocacia ou saúde e, portanto, mais uma forma de integração a sociedade. 
Apesar de eventuais diferenças culturais, conseguiram preservar e transmitir muitos elementos da terra natal. Hoje, a cultura libanesa está inserida na cultura brasileira, como também a de outras etnias e realizam um movimento de criação cultural único, formado pelas mais variadas referências e manifestando-se de diferentes formas no espaço urbano analisado.

\section{CONSIDERAÇÕES FINAIS}

Ao adentrarmos na vida dos libaneses, por meio das entrevistas, verificamos mais explicitamente a multiplicidade de caminhos pelos quais a emigração poderia ser acessada. Mais que uma necessidade latente aos sujeitos, esta se nutria das possibilidades emergidas conjunturalmente, de moradia, de acolhimento familiar, de emprego nas zonas urbanas, ou de associar-se em trabalhos (em lojas, ou na venda ambulante) junto a compatriotas. Uma opção estudada dentro dos termos de uma cultura migratória, que reuniu elementos de diferentes gerações, entremeados em estruturas e contingências familiares, cujos limites pautavam um horizonte de expectativas, em certa medida, maleável e sujeito constantemente a inéditas configurações.

Este trabalho vem ao encontro do pensamento desenvolvido por Massey (2000), que tem uma proposta de ver a construção dos lugares de uma forma progressista, sem discursos auto-afirmadores que, em certa medida, geram preconceitos para com as minorias, discriminando-as e, as vezes, ignorando as diferenças, como se os espaços se desenvolvessem de forma linear e homogênea.

O movimento de criação do lugar se dá de forma articulada com o global, numa via de cooperação mútua, em que os fatores globais se materializam no lugar de forma diferenciada, conforme o espaço em que isso ocorre, e essas diferenças que existem em cada lugar alimentam e impulsionam a criação dos componentes e ideias do global.

Os textos produzidos para mostrar o processo histórico de formação da cidade de Guarapuava funcionam como repressores das contradições e variantes que existem na formação cultural da sociedade local, e também funciona como uma resolução dessas contradições, pois, ao tentar eliminar as diferenças, os autores 
"resolvem" o problema, fazendo com que seu foco principal ignore os conflitos existentes.

As tradições que parecem ou alegam ser antigas são muitas vezes de origem bastante recentes e algumas vezes inventadas. "Tradição inventada significa um conjunto de práticas, de natureza ritual simbólica, que buscam inculcar certos valores e normas de comportamentos através da repetição" (HALL, 1999, p. 54).

As pessoas são tentadas a criar discursos onde recuam defensivamente para um passado remoto onde existiu um "tempo perdido" em que o município era grande, a coragem dos "heróis" era maior, a cidade tinha mais importância e assim são tentadas a restaurar identidades passadas.

Nesse processo se constrói o significado, por meio de uma dinâmica de referências e diferenças em relação a outros discursos e ideologias históricas, levando em consideração um desenvolvimento homogêneo do lugar, que não acontece na realidade. A criação e o fortalecimento dessas identidades locais podem ser pensados como uma reação defensiva, dos membros de grupos dominantes que se sentem ameaçados pela presença de outras culturas e buscam a criação de novos ícones culturais e viajam ao passado em busca de elementos que mecham com o imaginário das pessoas que vivem no lugar.

Assim, podemos afirmar que os discursos sobre o desenvolvimento histórico da cidade de Guarapuava PR devem levar em conta os diferentes grupos culturais que aqui viveram e que hoje se territorializam nas áreas urbanas, sem a busca de afirmação de um ou outro grupo como mais relevante na construção do lugar, mas pensando na ação de todos e em conjunto.

\section{REFERÊNCIAS}

ABREU, M. de A. Sobre a memória das cidades. Território, Rio de Janeiro, ano III, $\mathrm{n}^{\circ} 4$, p. 5-26, 1998.

CABREIRA, M. M. Cultura e identidade em São Paulo: a imigração síria e libanesa. EccoS revista científica. Volume 03, ano 1, São Paulo, 2001.

COHEN, Y. História oral: metodologia, um modo de pensar, um modo de transformar as ciências sociais? Ciências Sociais Hoje. São Paulo, 1993. 
COLOGNESE, S. A.; MÉLO, J. L. B. A técnica da entrevista na pesquisa social. Cadernos de Sociologia, Porto Alegre, v. 9, p. 143-159, 2008.

ELIAS, Norbert; e SCOTSON, John. L. Os estabelecidos e os outsiders: sociologia das relações de poder a partir de uma comunidade. Rio de Janeiro: Zahar, 2000.

DONATELLI, D. D. O sentido da memória. Cidade, São Paulo: Departamento do Patrimônio Histórico, 1996.

FIGOLI, L. H. e VILELA, E. M.. Migração internacional, multiculturalismo e identidade: sírios e libaneses em Minas Gerais. In: XIV Encontro Nacional de Estudos Populacionais, ABEP, realizado em Caxambú- MG. 2004.

FOUCAULT, M. A arqueologia do saber. 7ed. - Rio de Janeiro: Forense Universitária, 2008.

GATTAZ, André. História oral da imigração libanesa para o Brasil - 1880 a 2000. 2001.173 p. Tese (doutorado em História Social), Faculdade de Filosofia, Letras e Ciências Humanas da Universidade de São Paulo.

GOETTERT, J. D. Paradoxos do lugar mundo: Brasileiros e identidades. In: SPOSITO, E. S; BOMTEMPO, D. C. e SOUSA, A. A. (Org.). Geografia e migração: movimentos, territórios e territorialidades. Editora Expressão Popular, São Paulo, 2010. p. 15 a 36.

GASKELL, G. Entrevistas Individuais e Grupais. In: BAUER, M. W. GASKELL, G. Pesquisa Qualitativa com texto, imagem e som: um manual prático. Trad. Pedrinho Guareschi. Petrópolis: Vozes, 2008.

FIGOLI, L. H. e VILELA, E. M.. Migração internacional, multiculturalismo e identidade: sírios e libaneses em Minas Gerais. In: XIV Encontro Nacional de Estudos Populacionais, ABEP, realizado em Caxambú- MG. 2004.

HAESBAERT, R. O mito da desterritorialização. 4aa ed. Rio de Janeiro: Editora Bertrand, 2009.

Território e Multiterritorialidade: um debate. GEOgraphia, Rio de Janeiro, ano IX, n. 17, p. 19-45, julho de 2007.

HALL, S. "Race, culture, and comunications: looking backward and forward at cultural studies". In: STOREY, J. (ed.). What is cultural studies? London, Arnold, 1996, pp.336-343.

A centralidade da cultura: notas sobre as revoluções culturais do nosso tempo. Educação e Realidade, Porto Alegre, v. 22, n. 2, p. 15-46, 1999.

KHODR, H. O libanês no Brasil. 3 ed. Brasil - Líbano, 1987. 
KNOWLTON, Clark S. Sírios e libaneses: mobilidade social e espacial. São Paulo: Anhambi, 1955.

KRUGER, N. P. Guarapuava, Seu território, sua gente, seus caminhos, sua história. Curitiba: Editora Posigraf, 1999.

LESSER, J. A negociação da identidade nacional: imigrantes, minorias e a luta pela etnicidade no Brasil. São Paulo: Ed. UNESP, 2001.

MAIA, R. C. M. A identidade em contextos globalizados e multiculturais. Revista de Comunicação Social, Belo Horizonte n. 50, p.12-25, 1999.

MASSEY, D. Um sentido global no lugar. In: ARANTES, A. A. (org.) O espaço da diferença. Campinas/SP: Ed. Papirus, 2000. p. 176-185

MATOS, P. F.; PESSÔA, V. L. S. Observação e entrevista: construção de dados para a pesquisa qualitativa em geografia agrária. In: RAMIRES, J. C. L.; PESSÔA, V. L. S. (Org.) Geografia e Pesquisa Qualitativa: nas trilhas da investigação. Uberlândia: Assis, 2009. 279-291 p.

MCDOWELL, L. A transformação da geografia cultural. In: GREGORY, D.; MARTIN, R.; SMITH, G. (org.). Geografia humana: sociedade, espaço e ciência social. Rio de Janeiro: Zahas Ed. p. 159-188, 1999.

MINAYO, M. C. S. O desafio do conhecimento: pesquisa qualitativa em saúde. 11 ed. São Paulo: Hucitec, 2008.

O Pharol. Guarapuava 09 de Abril de 1922, ano IV

YKEGAYA, T. G. Imigração árabe em Foz do Iguaçu: A construção de uma identidade étnica. 2006. 196 p. Dissertação de mestrado, Universidade Estadual do Oeste do Paraná (UNIOESTE), Cascavel, Paraná.

SANTOS, M. A natureza do espaço: técnica e tempo, razão e emoção. 4⿳亠丷a edição. São Paulo: Editora da Universidade de São Paulo, 2006.

SOARES, W. Análise de redes sociais e os fundamentos teóricos da migração internacional. Revista Brasileira de Estudos População, Campinas, v. 21, n. 1, p. 101-116, jan./jun. 2004

SOUZA, M. J. L. DE. O território: sobre espaço e poder, autonomia e desenvolvimento. In: CASTRO, I. E. de; CORREA, R. L.; GOMES, P. C. da C. (org.) Geografia: conceitos e temas. Rio de Janeiro: Bertrand, 2001. p. 77-116.

TEIXEIRA, L. C. Reminiscências do passado. Guarapuava: Esquema, 1993. 168p. 